\title{
GRAVITY AND MAGNETIC STUDY OF YUCCA WASH, SOUTHWEST NEVADA
}

\author{
By \\ V.E. Langenheim, D.A. Ponce, H.W. Oliver, and R.F. Sikora
}

1993

Open-File Report 93-586-A

\section{DISCLAIMER}

This report was prepared as an account of work sponsored by an agency of the United States Government. Neither the United States Government nor any agency thereof, nor any of their employees, makes any warranty, express or implied, or assumes any legal liability or responsibility for the accuracy, completeness, or usefulness of any information, apparatus, product, or process disclosed, or represents that its use would not infringe privately owned rights. Reference herein to any specific commercial product, process, or service by trade name, trademark, manufacturer, or otherwise does not necessarily constitute or imply its endorsement, recommendation, or favoring by the United States Government or any agency thereof. The views and opinions of authors expressed herein do not necessarily state or reflect those of the United States Government or any agency thereof. 


\section{DISCLAIMER}

Portions of this document may be illegible in electronic image products. Images are produced from the best available original document. 


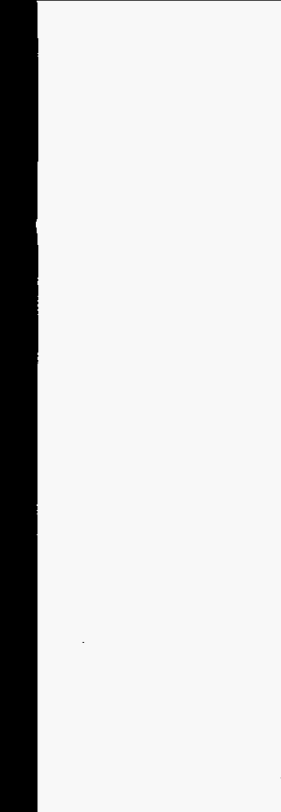




\section{CONTENTS}

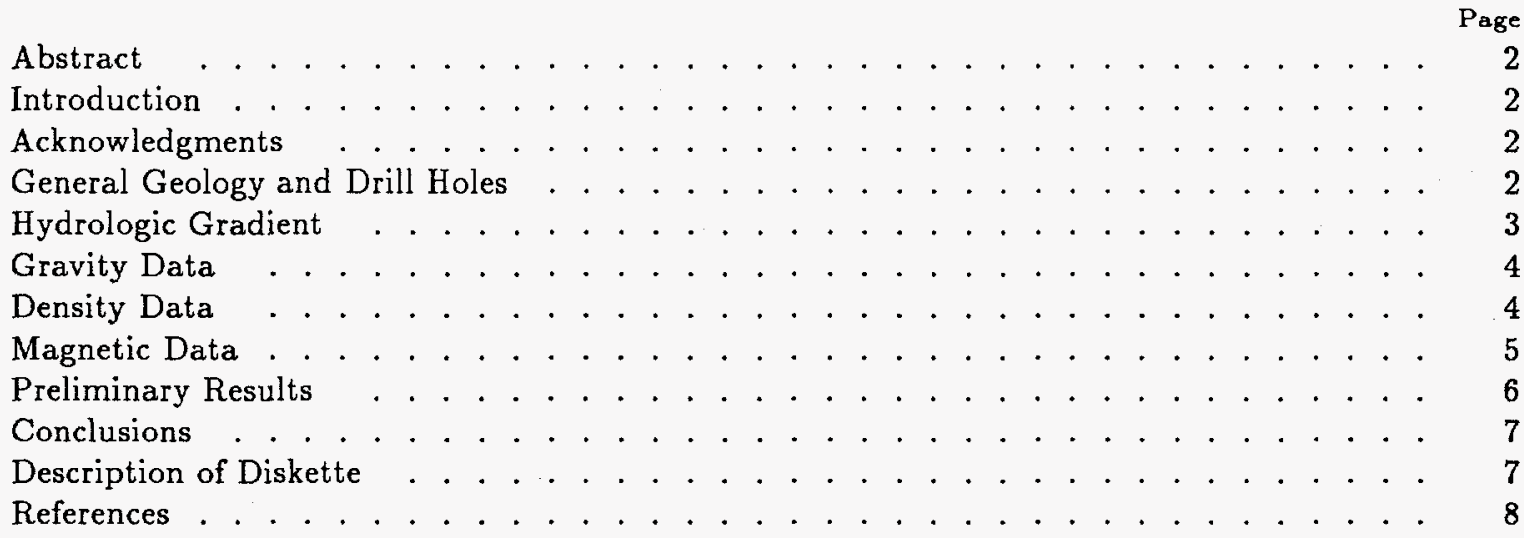

\section{ILLUSTRATIONS}

Page

Figure 1. Index map of study area . . . . . . . . . . . . . . . . . . . . . . . . 11

2a. Gravity, magnetic, and topography profile of line YA . . . . . . . in pocket

2b. Gravity, magnetic, and topography profile of line YB . . . . . . . . in pocket

2c. Gravity, magnetic, and topography profile of line $\mathrm{YC}$. . . . . . . . in pocket

2d. Gravity, magnetic, and topography profile of line YD . . . . . . . . in pocket

2e. Gravity, magnetic, and topography profile of line YE . . . . . . . . . in pocket

2f. Gravity, magnetic, and topography profile of line YF . . . . . . . . . in pocket

3a. Topography and gravity profile of line YC . . . . . . . . . . . . . . . . 12

3b. Topography and gravity profile of line YF . . . . . . . . . . . . . . . . 13

\section{TABLES}

TABLE 1. Physical properties of rock samples 


\section{Abstract}

Gravity and ground magnetic data were collected along five traverses across and one traverse along Yucca Wash in the southwest quadrant of the Nevada Test Site. Two additional ground magnetic profiles were collected approximately $100 \mathrm{~m}$ to either side of the longitudinal profile. These data do not indicate major vertical offsets greater than 100 $\mathrm{m}$ using a density contrast of 0.2 to $0.3 \mathrm{~g} / \mathrm{cm}^{3}$ along the proposed Yucca Wash fault. A broad magnetic high coincides with the location of the hydrologic gradient. Density profiling, a technique used to determine the average density of small topographic features, suggests that the density of near-surface material in the vicinity of Yucca Wash is about $2.0 \mathrm{~g} / \mathrm{cm}^{3}$.

\section{Introduction}

A gravity and magnetic investigation of Yucca Wash was begun as part of an effort to help geologically characterize Yucca Mountain as a potential site for the storage of commercial spent nuclear fuel and high-level radioactive waste. The study area is in the southwest quadrant of the Nevada Test Site (NTS) and is bounded by Yucca Mountain to the west, Timber Mountain area (Dome Mountain) to the north, Fortymile Canyon to the east and Midway Valley to the south (fig. 1). These data were specifically collected to aid in locating a drill-hole to help characterize the abrupt change in waterlevel altitude (hereafter referred to as the "hydrologic gradient") observed between wells UE-25 WT\#6 and UE-25 WT\#16 (O'Brien, 1991; WT\#6 aad WT\#16, fig. 1), and to determine the ground geophysical expression, if any, of the Yucca Wash fault proposed by Bath and Jahren (1984, fig. 19) on the basis of aeromagnetic data.

\section{Acknowledgments}

S.C. Kuehn, S.L. Snyder, and R.V. Allen of the U.S. Geological Survey (USGS) assisted in the gravity and magnetic observations. Raytheon Services Nevada provided elevation and location control.

\section{General Geology and Drill Holes}

Yucca Wash is a northwest-trending valley that drains southeastward and cuts across the general north-south trend of central Yucca Mountain and its major faults. These faults are well documented by geologic mapping, whereas the Yucca Wash fault is inferred by connecting the northern boundaries of a series of discontinuous aeromagnetic highs (Bath and Jahren, 1984). This buried fault presumably extends diagonally across the northern end of Midway Valley and terminates in the vicinity of the Paintbrush Canyon fault (Scott and Bonk, 1984 - see fig. 1, this report). Geologic mapping indicates that a fault of more than $10 \mathrm{~m}$ vertical offset of the Tiva Canyon member of the Paintbrush Tuff is unlikely to exist along Yucca Wash (Scott and others, 1984), although the aeromagnetic anomaly would suggest at least $70 \mathrm{~m}$ of vertical offset (Bath and Jahren, 1984).

Scott and Castellanos (1984) have characterized Yucca Wash as a "shear zone" on the basis of its approximate $45^{\circ}$ strike relative to the dominant north-south trending valleys and faults in the area. Scott and Bonk (1984) interpreted Yucca Wash as a concealed right-lateral strike-slip fault; however, previous geologic maps (Christiansen and Lipman, 1965; Byers and others, 1976) do not indicate the presence of any northwest-trending faults in this area. O'Neill and others (1992) interpret the central part 
of the wash to be a normal fault connecting the left-stepping Bow Ridge fault with the Solitario Canyon fault.

The general stratigraphy that underlies Yucca Wash is composed of Precambrian rocks, Paleozoic rocks, a series of Miocene ash-flow tuffs interbedded with relatively thin ash-fall and re-worked tuffs, and late Tertiary and Quaternary surficial deposits (Snyder and Carr, 1984, table 1). Pre-Cenozoic sedimentary and metamorphic rocks in the study area are predominantly limestone and dolomite, with lesser amounts of argillite, quartzite, and marble, and are exposed in the northeastern part of the study area at Calico Hills. The Paleozoic Lone Mountain Dolomite and Roberts Mountain Formations were penetrated in drill-hole UE-25p\#1 west of Fran Ridge (fig. 1, p\#1), at depths of 1,244 and 1,667 m, respectively (Muller and Kibler, 1984).

Five major Miocene volcanic units (Tv) occur at Yucca Mountain and vicinity; in ascending order these are: (1) older ash-flow tuffs, (2) Lithic Ridge Tuff, (3) Crater Flat Tuff, (4) tuffaceous beds of Calico Hills, and (5) Paintbrush Tuff. The entire Yucca Mountain volcanic section was observed in exploratory drill-hole USW G-1 (fig. 1, G-1) on the east flank of Yucca Mountain (Spengler and others, 1981). The Crater Flat Tuff is composed of the Tram, Bullfrog, and Prow Pass Members. The Paintbrush Tuff is composed of the Topopah Spring, Pah Canyon, Yucca Mountain and Tiva Canyon Members, but the Yucca Mountain member is absent at Yucca Wash according to well data (see below). Ash-flow tuffs in the area vary from densely welded to partially welded tuffs. Moderately to densely welded tuffs include the Topopah Spring and Tiva Canyon Members of the Paintbrush Tuff. Otherwise, the majority of the tuffs are partially welded to non-welded. Northeast of Yucca Wash are exposures of the rhyolite lavas of Fortymile Canyon. These rhyolites are not exposed at Yucca Mountain and are younger than the tuff sequence exposed at Yucca Mountain, but are relevant to our study at Yucca Wash.

The valley containing Yucca Wash has been penetrated by two drill holes, UE-25 WT\#6 and UE-25 WT\#16 (fig. 1). UE-25 WT\#6 is located about halfway between profiles YC and YD. UE-25 WT\#16 is almost on the concealed projection of the Bow Ridge fault just south of profile YB.

UE-25 WT\#6 was drilled in 1983 to a depth of $387 \mathrm{~m}$ and encountered the 13.1 Ma Topopah Spring Member of the Paintbrush Tuff (depths 0-117 m) and the tuffaceous beds of Calico Hills (depths 117-383 m; Muller and Kibler, 1985, p. 19). The hole bottomed in the Calico Hills unit. UE-25 WT\#16, drilled in 1983, also encountered the Topopah Spring Member (depths of 175-326 m) and tuffaceous beds of Calico Hills (depths of 326-521 m). Overlying the Topopah Springs member are the Tiva Canyon (0$139 \mathrm{~m}$ ) and Pah Canyon (139-175 m) members of the Paintbrush tuff. UE-25 WT\#16 bottomed at $521 \mathrm{~m}$ (fig. 2). The base of the Topopah Spring member of the Paintbrush tuff drops from $1197 \mathrm{~m}$ above sea level at UE-25 WT\#6 to $885 \mathrm{~m}$ above sea-level at UE25 WT\#16. Thus, the Miocene volcanic beds have an apparent southeasterly dip, dropping at least $175 \mathrm{~m}$ relative to the surface over the approximately $3.3 \mathrm{~km}$ distance between UE-25 WT\#6 and UE-25 WT\#16.

\section{Hydrologic Gradient}

The southeast section of Yucca Wash and adjacent hills is of particular interest to the possible storage of high-level radioactive waste at Yucca Mountain because of the large drop in the water-level elevation between wells UE-25 WT\#6 and UE-25 WT\#16 (J.B. Czarnecki, written commun., 1992; Ervin and others, 1993). The water level in UE25 WT\#6 is $1,035 \mathrm{~m}$ above sea level and nearly $300 \mathrm{~m}$ higher than that in UE-25 WT\#16 located only about $3,000 \mathrm{~m}$ to the southeast representing an average $10 \%$ grade. Farther 
south, the water-level elevation drops only $8 \mathrm{~m}$ in a horizontal distance of about $4,000 \mathrm{~m}$ to the center of the proposed repository and remains nearly level ( $\pm 2 \mathrm{~m})$ for a radial distance of several kilometers around the repository.

\section{Gravity Data}

Detailed gravity data were collected along six profiles (fig. 2a-f) across Yucca Wash (fig. 1) using LaCoste and Romberg gravity meters G17C and G614. Gravity meter performance and calibration factors were checked over the Mt. Charleston gravity meter calibration loop in the Spring Mountains, Nevada (Ponce and Oliver, 1981). Gravity data were reduced using the Geodetic Reference System of 1967 (International Union of Geodesy and Geophysics, 1971) and referenced to the International Gravity Standardization net 1971 gravity datum (Morelli, 1974, p. 18) via base station MERC at the USGS core library building at Mercury, Nevada (Ponce and Oliver, 1981, p. 13). Because of recent building construction near base station $\mathrm{MERC}$, it now has a new value of $979,518.91 \mathrm{mGal}$, determined by repeated ties to nearby station TCCA which is located on basement rocks. Gravity data were reduced to complete Bouguer anomalies using reduction densities of $2.67 \mathrm{~g} / \mathrm{cm}^{3}$ and $2.00 \mathrm{~g} / \mathrm{cm}^{3}$ and include earth-tide, instrument drift, free-air, Bouguer, latitude, curvature, and terrain corrections. In general, observed gravity data are accurate to about $0.05 \mathrm{mGal}$, while Bouguer anomalies are accurate to about 0.1 to $0.2 \mathrm{mGal}$.

Gravity stations were surveyed using an electronic-distance-measurement instrument and station elevations are accurate to within about $0.03 \mathrm{~m}$ from a reference bench mark. In general, gravity stations were spaced $50 \mathrm{~m}$ apart.

Terrain corrections were computed to a radial distance of $167 \mathrm{~km}$ and involved a 3-part process: (1) Hayford-Bowie zones A and B with an outer radius of $68 \mathrm{~m}$ were estimated in the field with the aid of tables and charts, or sketched and later calculated in the office, (2) Hayford-Bowie zones C and D with an outer radius of $590 \mathrm{~m}$ were calculated by averaging compartment elevations on a circular template based on Hayford's system of zones (Swick, 1942, p. 66), and (3) terrain corrections from a distance of $0.59 \mathrm{~km}$ to $167 \mathrm{~km}$ were calculated using a digital elevation model and a procedure by Plouff (1977). Small amplitude errors in some of the profiles may be related to small errors in the terrain corrections, particularly where profiles cross topographic features such as hills.

\section{Density Data}

Sources of rock density information are available from rock sampling, core sampling, density profiling and geophysical logs. Mean densities of more than 400 rock samples from the NTS were summarized by Ponce (1981, table 3). Densities of additional rock samples from within the study area are shown in table 1. Grain densities were determined by weighing the sample in air, then weighing the sample submerged in water using an electronic balance equipped with a stirrup and suspending the sample by a wire. Grain density was calculated from the difference of the two weighings, using Archimedes' principle:

$$
\mathrm{r}=\mathrm{W}_{\mathrm{a}} /\left(\mathrm{W}_{\mathrm{a}}-\mathrm{W}_{\mathrm{w}}\right)
$$

where $\mathrm{r}=$ grain density, $\mathrm{W}_{\mathrm{a}}=$ weight in air, and $\mathrm{W}_{\mathrm{W}}=$ weight in water. Saturated and dry bulk densities were also calculated. 
A density log of well UE-25 WT\#6 (Nelson and others, 1991) shows an average density of about $2.00 \mathrm{~g} / \mathrm{cm}^{3}$, ranging from about $1.75 \mathrm{~g} / \mathrm{cm}^{3}$ to $2.20 \mathrm{~g} / \mathrm{cm}^{3}$. The uppermost $30 \mathrm{~m}$ of the tuffaceous beds of Calico Hills is characterized by lower densities, fluctuating between 1.75 and $2.0 \mathrm{~g} / \mathrm{cm}^{3}$ whereas the Topopah Spring member of the Paintbrush Tuff has an average density of about $2.20 \mathrm{~g} / \mathrm{cm}^{3}$. Densities from a log of UE25 WT\#16 also average around $2.00 \mathrm{~g} / \mathrm{cm}^{3}$. The Pah Canyon member of the Paintbrush Tuff has an average density of less than $1.80 \mathrm{~g} / \mathrm{cm}^{3}$; the Topopah Spring member and the tuffaceous beds of Calico Hills, about $2.1 \mathrm{~g} / \mathrm{cm}^{3}$.

Density profiling (Nettleton, 1976) is an interpretive technique using gravity profiles to determine the average density across small topographic features by selecting the reduction density that exhibits the least correlation with the topography. Because the gravity station spacing of the traverses across Yucca Wash were closely spaced and because at least one of the traverses crosses topographic features of low relief, including Yucca Wash, the data were well suited to the density profiling technique. Six Bouguer reduction densities, ranging from $1.60 \mathrm{~g} / \mathrm{cm}^{3}$ to $2.67 \mathrm{~g} / \mathrm{cm}^{3}$, were used to compute density profiles for one profile crossing Yucca Wash (YC) and the longitudinal profile along Yucca Wash (YF; Fig. 4a,b).

The density profile of line YC (fig. 3a), which crosses Yucca Wash, indicates that the density of a cliff (located by an arrow) is about 1.80 to $2.00 \mathrm{~g} / \mathrm{cm}^{3}$. The cliff is composed of Tertiary volcanic rocks of the Calico Hills tuff. As the topographic expression of the profile decreases it becomes more difficult to distinguish which reduction density has the least correlation to topography. For the longitudinal profile YF (Fig. 3b), which has virtually no topographic expression except for a gentle southward slope, the density profiling technique is not really applicable, but is shown for comparison. Although the YF profile shows very different profiles based on different reduction densities, a reduction density of about $2.00 \mathrm{~g} / \mathrm{cm}^{3}$ provides the least variation in gravity values. In addition, density profiling on several profiles collected in Fortymile Wash indicates that a density of about 1.80 to $2.00 \mathrm{~g} / \mathrm{cm}^{3}$ produces a minimum correlation of the gravity anomaly data to topography (Ponce and others, 1992). Thus, based on the results of YC, YF, and Fortymile Wash and the density logs from UE-25 WT\#6 and UE-25 WT\#16, a reduction density of $2.00 \mathrm{~g} / \mathrm{cm}^{3}$ has been chosen for all the gravity profiles and probably represents the average density of the near-surface layer in the vicinity of Yucca Wash.

In conclusion, the density data described above indicate that there are significant density contrasts between alluvium, zeolitized tuffs, partly-welded tuffs, and welded tuffs that range from about $0.2 \mathrm{~g} / \mathrm{cm}^{3}$ between zeolitized, partly-welded tuffs and welded tuffs and up to about $0.6 \mathrm{~g} / \mathrm{cm}^{3}$ between unwelded and welded tuffs. An average density contrast of about 0.2 to $0.3 \mathrm{~g} / \mathrm{cm}^{3}$ works well for estimating vertical offsets along faults in Midway Valley (Ponce and others, 1992; Ponce, 1993).

\section{Magnetic Data}

Ground magnetic data were gathered along the five profiles across Yucca Wash and three profiles along Yucca Wash (fig. 1; fig. 2a-f). A Geometrics portable proton precession magnetometer model G-816 and base station magnetometer G-826A were used to collect data with the sensor at $2.4 \mathrm{~m}$ above the surface. Because the anomalies of interest were believed to be small ( 20 to $50 \mathrm{nT}$ ) and the profile lines were long (about 1 to $6 \mathrm{~km}$ ) a base station was usually used to make corrections for diurnal time variations of 
the Earth's magnetic field. The base station was located central to the area of investigation, e.g., near well UE-25 WT\#6, and readings were taken at 5-minute intervals or less. Magnetic observations are accurate to about $1 \mathrm{nT}$. Maximum station spacing was 20 paces or about $18 \mathrm{~m}$ while minimum spacing was 1 pace or about $1 \mathrm{~m}$. Locations of the two parallel, longitudinal profiles bordering the central profile along Yucca Wash are only approximately located and are only precisely known where transverse profiles were intersected.

\section{Preliminary Results}

The gravity data on the profiles crossing Yucca Wash do not indicate any major vertical offsets (greater than $100 \mathrm{~m}$ using a density contrast of 0.2 to $0.3 \mathrm{~g} / \mathrm{cm}^{3}$ and an infinite slab) along the Yucca Wash fault (YWF). It is difficult to trace from profile to profile any offset that might be related to the YWF. Magnetic data also do not suggest major vertical offsets along the YWF, nor do they suggest a consistent change in magnetic lithology across the proposed location of the fault. These data do not preclude the possibility of vertical or horizontal offsets along the proposed Yucca Wash fault; they only show that if faulting exists, it does not juxtapose rocks of differing densities or magnetic properties. Anomalies, described below, are present on the profiles, most notably on profiles YA, YB, and YE, that suggest the presence of faults. These faults may trend along the structurally dominant north-south direction or along the trend of the wash; with presently available data, it is not possible to determine the trend of these faults. Note that because of the uncertainty in the location of the inferred YWF, the locations shown as "YWF" on fig. 2a-e are only accurate to about $100 \mathrm{~m}$.

In particular, profile YA (fig. $2 \mathrm{a}$ ) shows both gravity $(2 \mathrm{mGal})$ and magnetic $(600$ $\mathrm{nT}$ ) anomalies associated with the Paintbrush Canyon fault on the eastern part of the profile. The Bow Ridge fault is also well-expressed by a $\sim 0.7 \mathrm{mGal}$ anomaly on the western part of the profile, about $200 \mathrm{~m}$ east of where projected by Scott and Bonk (1984). The mapped projection of the YWF is located near a 0.5 to $0.7 \mathrm{mGal}$ gravity anomaly and a $150 \mathrm{nT}$ magetic anomaly at about $2000 \mathrm{~m}$, but other north-south trending faults located farther south in Midway Valley (Ponce and others, 1992, 1993; Ponce, 1993) could be responsible for these geophysical anomalies.

Profile YB (fig. 2b) shows a $0.5 \mathrm{mGal}$ anomaly at about $700 \mathrm{~m}$ close to the mapped Yucca Wash fault as well as a $500 \mathrm{nT}$ magnetic anomaly. Gradients in the gravity and magnetic fields indicate possible vertical offsets at about 1100 and $1300 \mathrm{~m}$. The Bow Ridge fault appears to be associated with a $0.4 \mathrm{mGal}$ anomaly, about $100 \mathrm{~m}$ west of its mapped location.

The next two profiles crossing Yucca Wash to the north, YC (fig. 2c) and YD (fig. 2d) indicate rather flat gravity signatures. YD, in particular, is nearly featureless. Low gravity values at the ends of the profile indicate topographic slopes of low-density rock as low as $1.7 \mathrm{~g} / \mathrm{cm}^{3}$. Rapid changes in magnetic intensity on the easternmost $300 \mathrm{~m}$ of YC and the westernmost $100 \mathrm{~m}$ of YD are caused by close proximity to randomly oriented, strongly magnetic float. The broad central magnetic high at about $750 \mathrm{~m}$ along YD corresponds to a topographic ridge. The YWF, if present, does not have much, if any, of a geophysical expression along these two profiles.

Gravity anomalies (gradients) may indicate possible faults at $300 \mathrm{~m}, 500 \mathrm{~m}, 950$ $\mathrm{m}, 1300 \mathrm{~m}$, and $1550 \mathrm{~m}$ along profile YE (fig. 2e). The mapped location of YWF occurs within a gravity low at about $450 \mathrm{~m}$, corresponding with a magnetic gradient. 
The three ground magnetic profiles of YF (fig. 2f) show a large (900 to $1250 \mathrm{nT}$ ) anomaly just north of UE-25 WT\#6. The maximum depth to the top of the source of this anomaly is $\sim 100 \mathrm{~m}$ based on gradient analysis. A small $(<0.5 \mathrm{mGal})$ gravity low coincides with the location of the large magnetic anomaly. To the south of the $1000 \mathrm{nT}$ anomaly is a broad 200-300 nT magnetic high that appears to be deeper, but also associated with low gravity values. These magnetic highs appear at approximately the same location along all three profiles, perhaps indicating little or no (less than $250 \mathrm{~m}$ ) horizontal offset along the proposed YWF. The broad magnetic high may be related to the aeromagnetic high (Bath and Jahren, 1984) over Isolation Ridge, a topographic high located southwest of Yucca Wash. The broad magnetic high also coincides with the hydrologic gradient. The sharp, large-amplitude magnetic anomaly on profile YF West at about 3325 m occurs directly over water well UE-25 WT\#6.

\section{Conclusions}

Gravity and magnetic data across Yucca Wash do not indicate, but do not preclude major vertical offsets on the proposed Yucca Wash fault. A broad magnetic high along the longitudinal profiles is intriguing because of its location with respect to the hydrologic gradient. The magnetic high may limit the amount of horizontal offset as well. Additional geophysical data are needed in order to determine the source of this anomaly and its possible relationship, if any, with the hydrologic gradient. These gravity and magnetic studies show that they are useful for constraining vertical offsets and possibly horizontal offsets of suspected faults. Detailed gravity, magnetic, and electrical data could provide an effective means to define better the location of known or suspected faults and to locate concealed or unknown faults.$$
\text { os } T^{\prime} \text { 's copcription did not diskette are a diskette. }
$$

The data described in this report are available on $31 / 2$-inch, high-density, and doublesided diskette formatted for IBM personal computers. The diskette requires the following hardware: (1) an IBM personal computer or compatible computer running PC or MSDOS, and (2) a double-sided high-density disk drive. The diskette contains a total of 16 files:
}

readme.txt, a description of the gravity and magnetic data; $y w . c b a$, principal facts of gravity data; ya.grv, gravity data along profile $\mathrm{YA}$; $y b . g r v$, gravity data along profile $\mathrm{YB}$; $y c . g r v$, gravity data along profile $\mathrm{YC}$; yd.grv, gravity data along profile YD; ye.grv, gravity data along profile YE; $y f . g r v$, gravity data along profile YF; ya.mag, magnetic data along profile YA; yb.mag, magnetic data along profile YB; yc.mag, magnetic data along profile $\mathrm{YC}$; yd.mag, magnetic data along profile YD; ye.mag, magnetic data along profile $\mathrm{YE}$; yf.mag, magnetic data along profile YF; yfe.mag, magnetic data along profile YF east; and yfw.mag, magnetic data along profile YF west. 


\section{References}

Bath, G.D., and Jahren, C.E., 1984, Interpretations of magnetic anomalies at a potential repository site located in the Yucca Mountain area, Nevada Test Site: U.S. Geological Survey Open-File Report 84-120, 40 p. (NNA.870323.0194)

Byers, F.M., Carr, W.J., Christiansen, R.L., Lipman, P.W., Orkild, P.P., and Quinlivan, W.D., 1976, Geologic map of the Timber Mountain caldera area, Nye County, Nevada: U.S. Geological Survey Miscellaneous Investigations Series Map I-891, scale 1:48,000. (HQS.880517.1107)

Christiansen, R.L., and Lipman, P.W., 1965, Geologic map of the Topopah Spring NW quadrangle, Nye County, Nevada: U.S. Geological Survey Geologic Quadrangle Map GQ-444, scale 1:24,000. (HQS.880517.1118).

Ervin, E.M., Luckey, R.R., and Burkhardt, D.J., 1993, Summary of revised potentiometric-surface map for Yucca Mountain and vicinity, Nevada: Proceedings of the Fourth Annual International Conference on High Level Waste Radioactive Waste Management, Las Vegas, Nevada, April 26-30, 1993, American Nuclear Society, v. 2, p. 1554-1558. (NNA.940120.0058)

International Union of Geodesy and Geophysics, 1971, Geodetic Reference System 1967: International Association of Geodesy Special Publication no. 3, $116 \mathrm{p}$. (NNA.901127.0202)

Lipman, P.W., and McKay, E.J., 1965, Geologic map of the Topopah Spring SW quadrangle, Nye County, Nevada: U.S. Geological Survey Geologic Quadrangle Map GQ-439, scale 1:24,000. (HQS.880517.1317)

Morelli, C.(Ed.), 1974, The International Gravity Standardization Net, 1971: International Association of Geodesy Special Publication no. 4, 194 p. (NNA.901127.0203)

Muller, D.C., and Kibler, J.E., 1984, Preliminary analysis of geophysical logs from drill hole UE-25p\#1, Yucca Mountain, Nye County, Nevada, U.S. Geological Survey Open-File Report 84-649, 14 p. (HQS.880517.1353)

Muller D.C., and Kibler, J.E., 1985, Preliminary analysis of geophysical logs from the WT series of drill holes, Yucca Mountain, Nye County, Nevada: U.S. Geological Survey Open-File Report 86-46, 29 p. + 3 plates. (NNA.931029.0137)

Nelson, P.H., Muller, D.C., Schimschal, Ulrich, and Kibler, J.E., 1991, Geophysical logs and core measurements from forty boreholes at Yucca Mountain, Nevada: U.S. Geological Survey Geophysical Investiations Map GP-1001, 10 sheets + 64 p. + text. (NNA.920211.0022)

Nettleton, L.L., 1976, Gravity and magnetics in oil prospecting: New York, McGrawHill Book Company, 464 p. (HQS.880517.1353)

O'Brien, Grady, 1991, Water levels in periodically measured wells in the Yucca Mountain area, Nevada, 1989: U.S. Geological Survey Open-File Report 91-178, 51 p. (NNA.910708.0041) 
O'Neill, J. Michael, Whitney, John W., and Hudson, Mark R., 1992, Photogeologic and kinematic analysis of lineaments at Yucca Mountain, Nevada: Implications for strike-slip faulting and oroclinal bending: U.S. Geological Open-File Report 91623,24 p., scale 1:24,000. (NNA.921211.0174)

Plouff, Donald, 1977, Preliminary documentation for a FORTRAN program to compute gravity terrain corrections based on topography digitized on a geographic grid: U.S. Geological Survey Open-File Report 77-535, 45 p. (NNA.901127.0204)

Ponce, D.A., 1981, Preliminary gravity investigations of the Wahmonie site, Nye County, Nevada: U.S. Geological Survey Open-File Report 81-522, 64 p. (HQS.880517.2824)

Ponce, D.A., 1993, Geophysical investigations of concealed faults near Yucca Mountain, southwest Nevada: American Nuclear Society Proceedings of the 4th Annual International Conference on High-Level Waste Management, v. 1, p. 168-174. (NNA.931025.0028)

Ponce, D.A., and Oliver, H.W., 1981, Charleston Peak gravity calibration loop, Nevada: U.S. Geological Survey Open-File Report 81-985, 20 p. (HQS.880517.2827)

Ponce, D.A., Kohrn, S.B., and Waddell, Sandra, 1992, Gravity and magnetic data of Fortymile Wash, Nevada Test Site, Nevada: U.S. Geological Survey Open-File Report 92-343, 33 p. (NNA.920714.0032)

Ponce, D.A., Langenheim, V.E., and Sikora, R.F., 1993, Gravity and magnetic data of Midway Valley, southwest Nevada: U.S. Geological Survey Open-File Report 93-540, 9 p., scale 1:12,000. (NNA.940418.0157)

Scott, R.B., and Bonk, Jerry, 1984, Preliminary geologic map of Yucca Mountain with geologic sections, Nye County, Nevada: U.S. Geological Survey Open-File Report 84-494, scale 1:48,000. (HQS.880517.1443)

Scott, R.B., and Castellanos, Mayra, 1984, Stratigraphic and structural relations of volanic rocks in drill holes USW GU-3 and USW G-3, Yucca Mountain, Nye County, Nevada: U.S. Geological Survey Open-File Report 84-491, 121 p. (NNA.890804.0017)

Scott, R.B., Bath, G.D., Flanigan, V.J., Hoover, D.B., Rosenbaum, J.G., and Spengler, R.W., 1984, Geological and geophysical evidence of structures in northwesttrending washes, Yucca Mountain, southern Nevada, and their possible significance to a nuclear waste repository in the unsaturated zone: U.S. Geological Survey Open-File Report 84-567, 23 p. (NNA.870519.0101)

Snyder, D.B., and Carr, W.J., 1984, Interpretation of gravity data in a complex volcanotectonic setting, southwestern Nevada: Journal of Geophysical Research, v. 89, no. B12, p. 10,193-10,206. (HQX.880801.0088)

Spengler, R.W., Byers, F.M., Jr., and Warner, J.B., 1981, Stratigraphy and structure of volcanic rocks in drill hole USW-G1, Yucca Mountain, Nye County, Nevada: U.S. Geological Survey Open-File Report 81-1349, 50 p. (NNA.870406.0222)

Swick, C.A., 1942, Pendulum gravity measurements and isostatic reductions: U.S. Coast and Geodetic Survey Special Publication 232, 82 p. (NNA.901204.0008) 
NOTE: Parenthesized numbers following each cited reference are for U.S. Department of Energy Office of Civilian Radioactive Waste Management Records Management purposes only and should not be used when ordering the publication. 


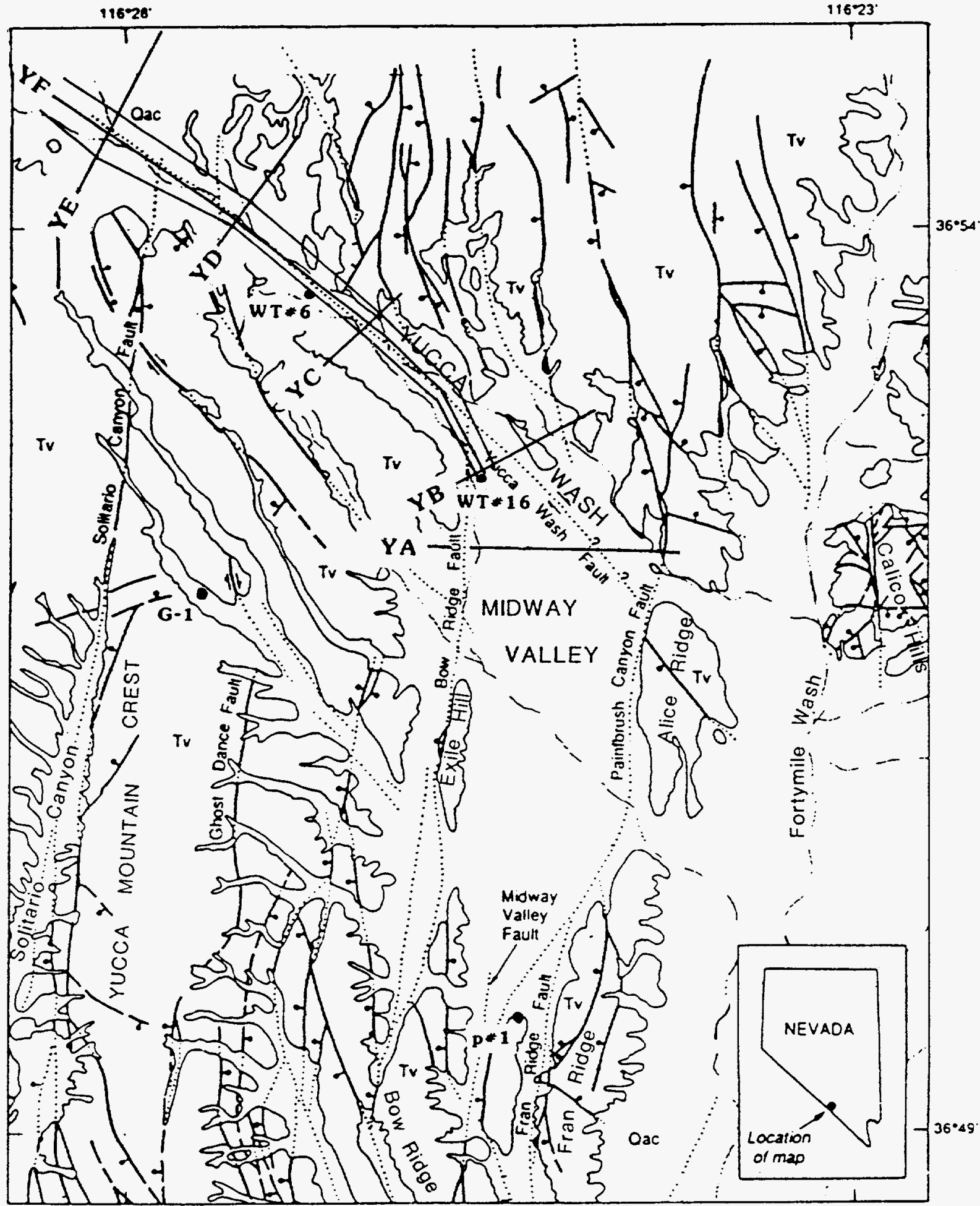

SCALE 1: 62500

$\stackrel{2}{1} \quad \mathrm{KM}^{\mathrm{KM}}$

Figure 1-Index map of the study area showing locations of gravity and magnetic profiles along and across Yucca Wash, pertinent drill-holes (•), and the proposed repository site. Tv, Tertiary volcanic rocks; Qac, Quaternary alluvium and colluvium. Bold lines, faults, dotted where concealed, ball and bar on downthrown side, arrows indicate relative movement. Geology taken from Lipman and McKay (1965). YF consists of three profiles. 

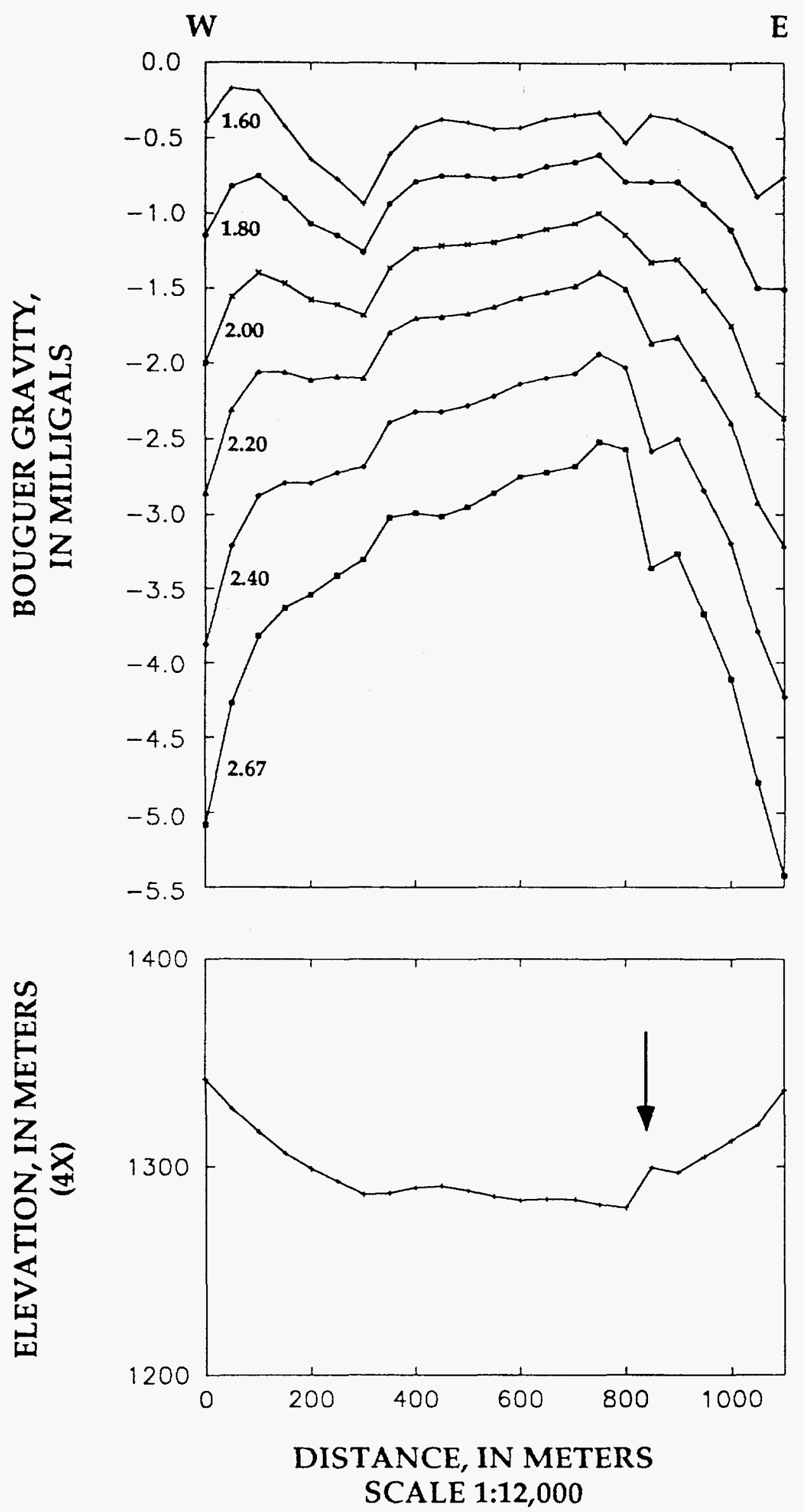

Fig. 3a. Topography and gravity profiles of line $\mathrm{YC}$ using reduction densities of 1.60,1.80.2.00, $2.20,2.40$ and $2.67 \mathrm{~g} / \mathrm{cm}^{3}$. 


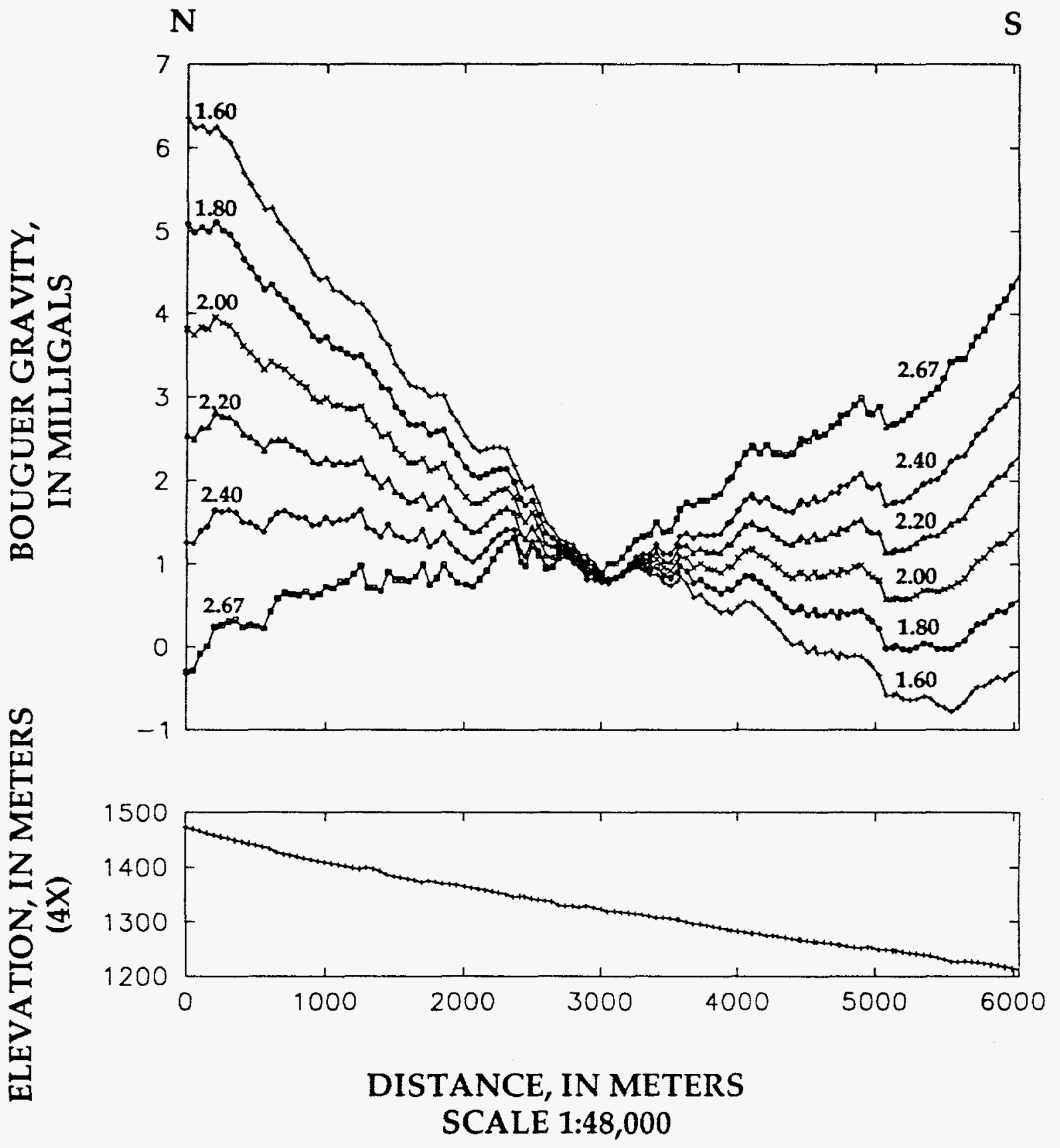

Fig. 3b. Topography and gravity profiles of line $\mathrm{YF}$ using reduction densities of 1.60 , $1.80,2.00,2.20,2.40$, and $2.67 \mathrm{~g} / \mathrm{cm}^{3}$. 
TABLE 1. Physical Properties of samples collected in Yucca Wash and Midway Valley

\begin{tabular}{|c|c|c|c|c|c|c|c|}
\hline $\begin{array}{l}\text { Sample } \\
\text { number }\end{array}$ & Latitude & Longitude & $\begin{array}{c}\text { Grain } \\
\text { Density, in } \\
\mathrm{g} / \mathrm{cm}^{3}\end{array}$ & $\begin{array}{c}\text { Saturated } \\
\text { Bulk Density, } \\
\text { In } \mathrm{g} / \mathrm{cm}^{3}\end{array}$ & $\begin{array}{c}\text { Dry Bulk } \\
\text { Density, in } \\
\mathbf{g}^{\prime} \mathrm{cm}^{3}\end{array}$ & $\begin{array}{l}\text { Susceptibility, in } \\
10^{-3} \mathrm{cgs} \text { units }\end{array}$ & Formation \\
\hline G1109 & $36^{\circ} 51.16^{\circ}$ & $116^{\circ} 25.75^{\circ}$ & 2.14 & 2.08 & 2.02 & .00 & 'Tiva Canyon member \\
\hline G1110 & $36^{\circ} 51.16^{\circ}$ & $116^{\circ} 25.72^{\prime}$ & 2.13 & 2.05 & 1.99 & .00 & Tiva Canyon member \\
\hline $\mathrm{T} 14 \mathrm{~W}$ & $36^{\circ} 51.17^{\circ}$ & $116^{\circ} 26.09^{\circ}$ & 2.29 & 2.05 & 1.87 & .00 & Tiva Canyon member \\
\hline G1586A & $36^{\circ} 51.16^{\circ}$ & $116^{\circ} 25.69^{\circ}$ & 2.24 & 2.16 & 2.09 & .00 & Tiva Canyon member \\
\hline G1586B & $36^{\circ} 51.16^{\circ}$ & $116^{\circ} 25.69^{\prime}$ & 2.27 & 2.21 & 2.16 & .20 & Tiva Canyon member \\
\hline G2100 & $36^{\circ} 50.79^{\circ}$ & $116^{\circ} 26.42^{\circ}$ & 2.32 & 2.30 & 2.29 & .30 & Tiva Canyon member \\
\hline G3127 & $36^{\circ} 49.69^{\circ}$ & $116^{\circ} 24.94^{\circ}$ & 2.27 & 2.24 & 2.21 & .00 & Tiva Canyon member \\
\hline G3TP1 & $36^{\circ} 49.98^{\circ}$ & $116^{\circ} 25.82^{\circ}$ & 2.13 & 2.10 & 2.07 & .00 & Tiva Canyon member \\
\hline G4TP1 & $36^{\circ} 51.67^{\prime}$ & $116^{\circ} 26.11^{\circ}$ & 2.25 & 2.20 & 2.15 & .20 & Tiva Canyon member \\
\hline G4TP3 & $36^{\circ} 51.41^{\circ}$ & $116^{\circ} 24.38^{\circ}$ & 2.29 & 2.15 & 2.10 & .20 & Tiva Canyon member \\
\hline YA151 & $36^{\circ} 52.21^{\circ}$ & $116^{\circ} 24.25^{\prime}$ & 2.33 & 2.31 & 2.30 & .30 & Topopah Spring member \\
\hline YATPI & $36^{\circ} 52.25^{\circ}$ & $116^{\circ} 25.99^{\prime}$ & 1.83 & 1.80 & 1.75 & .00 & Tiva Canyon member \\
\hline YB100 & $36^{\circ} 52.60^{\circ}$ & $116^{\circ} 25.77^{\prime}$ & 2.29 & 2.27 & 2.26 & .20 & Tiva Canyon member \\
\hline YB118 & $36^{\circ} 52.83^{\circ}$ & $116^{\circ} 25.24^{\circ}$ & 2.29 & 2.20 & 2.14 & .10 & Rhyolite lavas of Fortymile Canyon \\
\hline YB123 & $36^{\circ} 52.90^{\prime}$ & $116^{\circ} 25.09^{\prime}$ & 2.36 & 2.34 & 2.32 & .10 & Rhyolite lavas of Fortymile Canyon \\
\hline YB131 & $36^{\circ} 53.00^{\circ}$ & $116^{\circ} 24.85^{\circ}$ & 2.35 & 2.33 & 2.31 & .20 & Rhyolite lavas of Fortymile Canyon \\
\hline YCl00A & $36^{\circ} 53.25^{\circ}$ & $116^{\circ} 26.69^{\circ}$ & 1.89 & 1.64 & 1.36 & .00 & Pah Canyon member \\
\hline YC100B & $36^{\circ} 53.25^{\circ}$ & $116^{\circ} 26.69^{\prime}$ & 2.08 & 2.07 & 2.06 & .00 & Pah Canyon member \\
\hline YC117 & $36^{\circ} 53.56^{\circ}$ & $116^{\circ} 26.27^{\circ}$ & 2.21 & 2.16 & 2.11 & .10 & Pah Canyon member \\
\hline YC120 & $36^{\circ} 53.62^{\circ}$ & $116^{\circ} 26.20^{\circ}$ & 2.31 & 2.26 & 2.23 & .20 & Rhyolite lavas of Fortymile Canyon \\
\hline YD100 & $36^{\circ} 53.89^{\circ}$ & $116^{\circ} 27.42^{\prime}$ & 2.13 & 1.97 & 1.83 & .10 & Pah Canyon member \\
\hline YD129A & $36^{\circ} 54.53^{\circ}$ & $116^{\circ} 26.85^{\circ}$ & 2.44 & 2.42 & 2.41 & .20 & Rhyolite lavas of Fortymile Canyon \\
\hline YD129B & $36^{\circ} 54.53^{\circ}$ & $116^{\circ} 26.85^{\circ}$ & 2.37 & 2.31 & 2.27 & .20 & Rhyolite lavas of Fortymile Canyon \\
\hline YE100 & $36^{\circ} 54.19^{\circ}$ & $116^{\circ} 28.36^{\prime}$ & 2.34 & 2.30 & 2.26 & .10 & Topopah Spring member \\
\hline YE101 & $36^{\circ} 54.21^{\prime}$ & $116^{\circ} 28.34^{\circ}$ & 1.95 & 1.83 & 1.70 & .00 & $\begin{array}{l}\text { Tuffaceous beds of Calico Hills, non- } \\
\text { welded ash- flow tuff }\end{array}$ \\
\hline YE132 & $36^{\circ} 54.96^{\circ}$ & $116^{\circ} 27.87^{\circ}$ & 2.30 & 2.16 & 2.05 & .00 & Tuff of Pinyon Pass \\
\hline
\end{tabular}

The following number is for U.S. Department of Energy Office of Civilian Radioactive Waste Management Records Management purposes only and should not be used when ordering the publication: Accession number[NNA.940510.0001] 


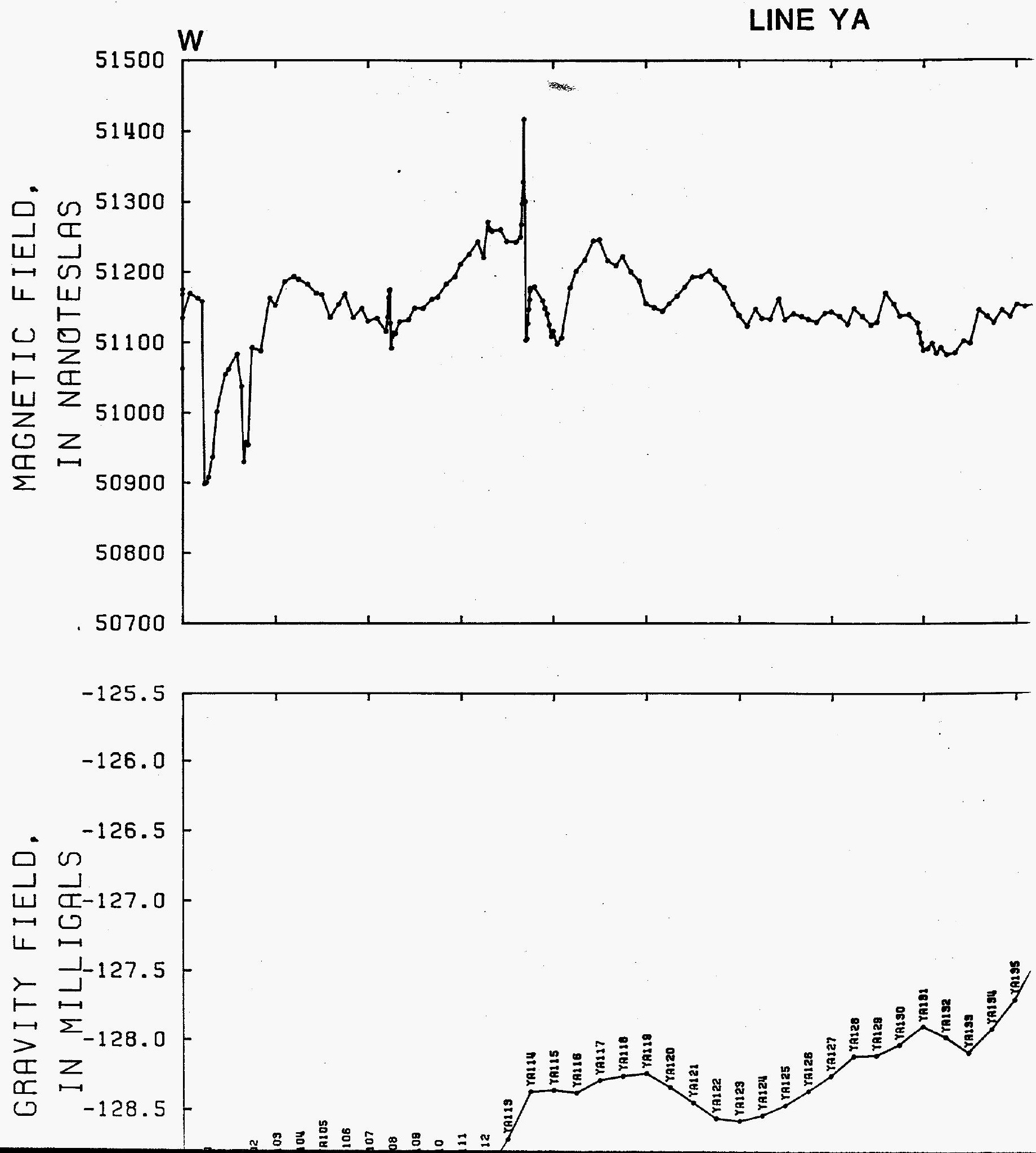



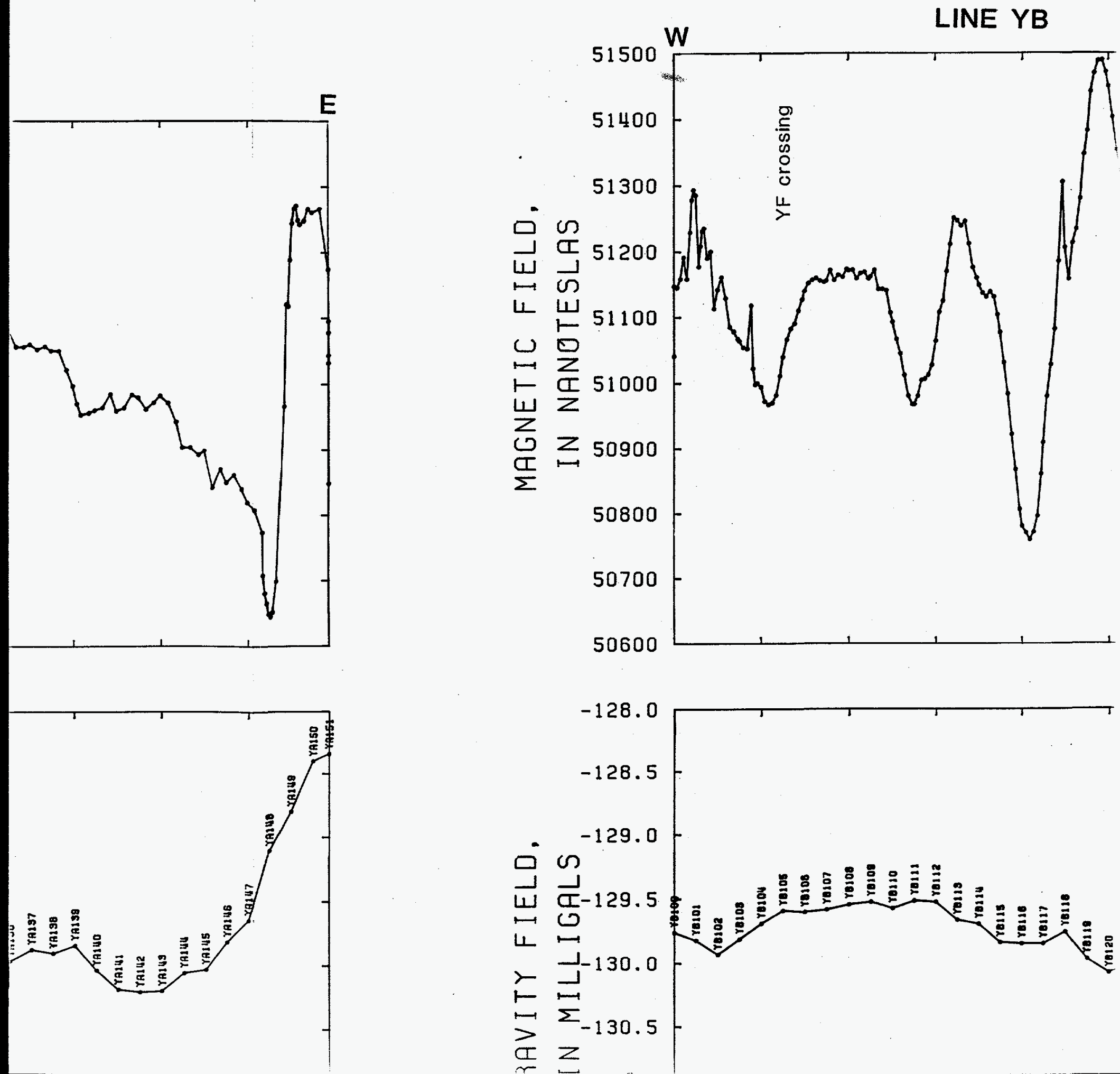
E
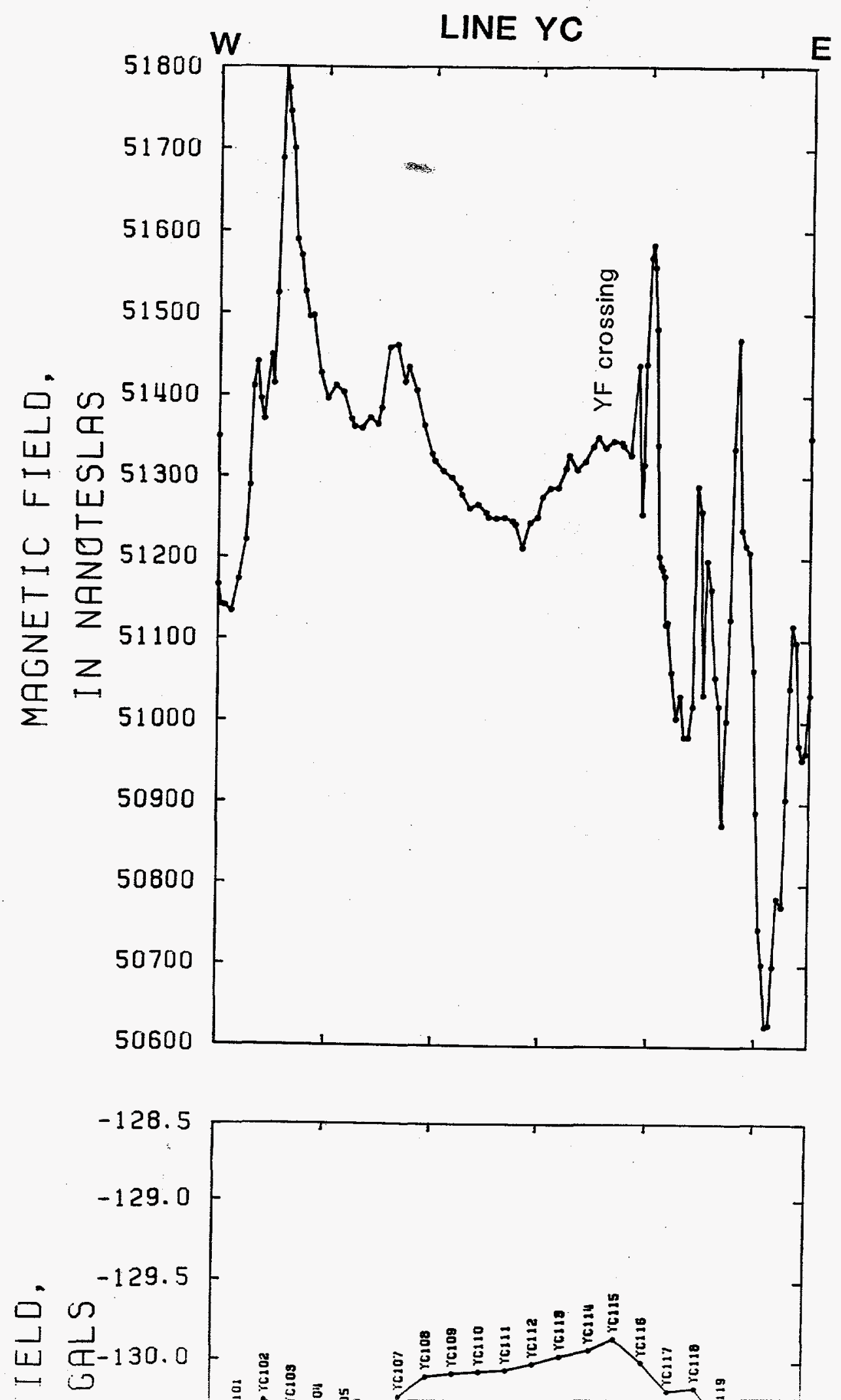
INE YC

E

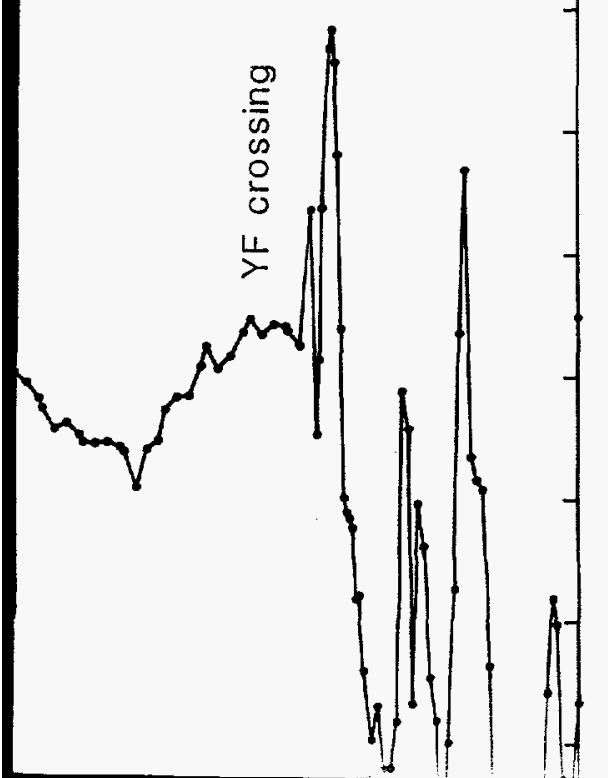

LINE YD

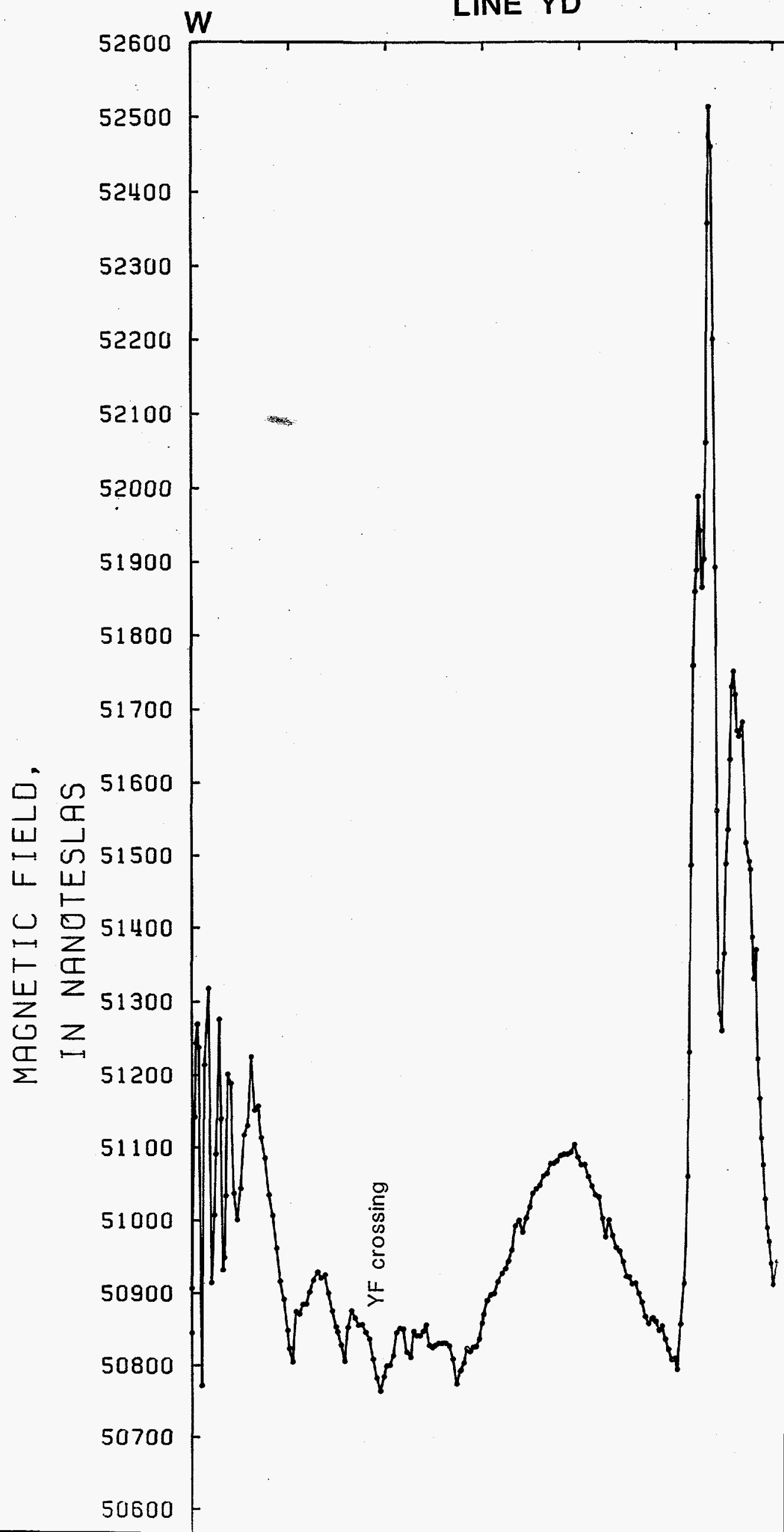




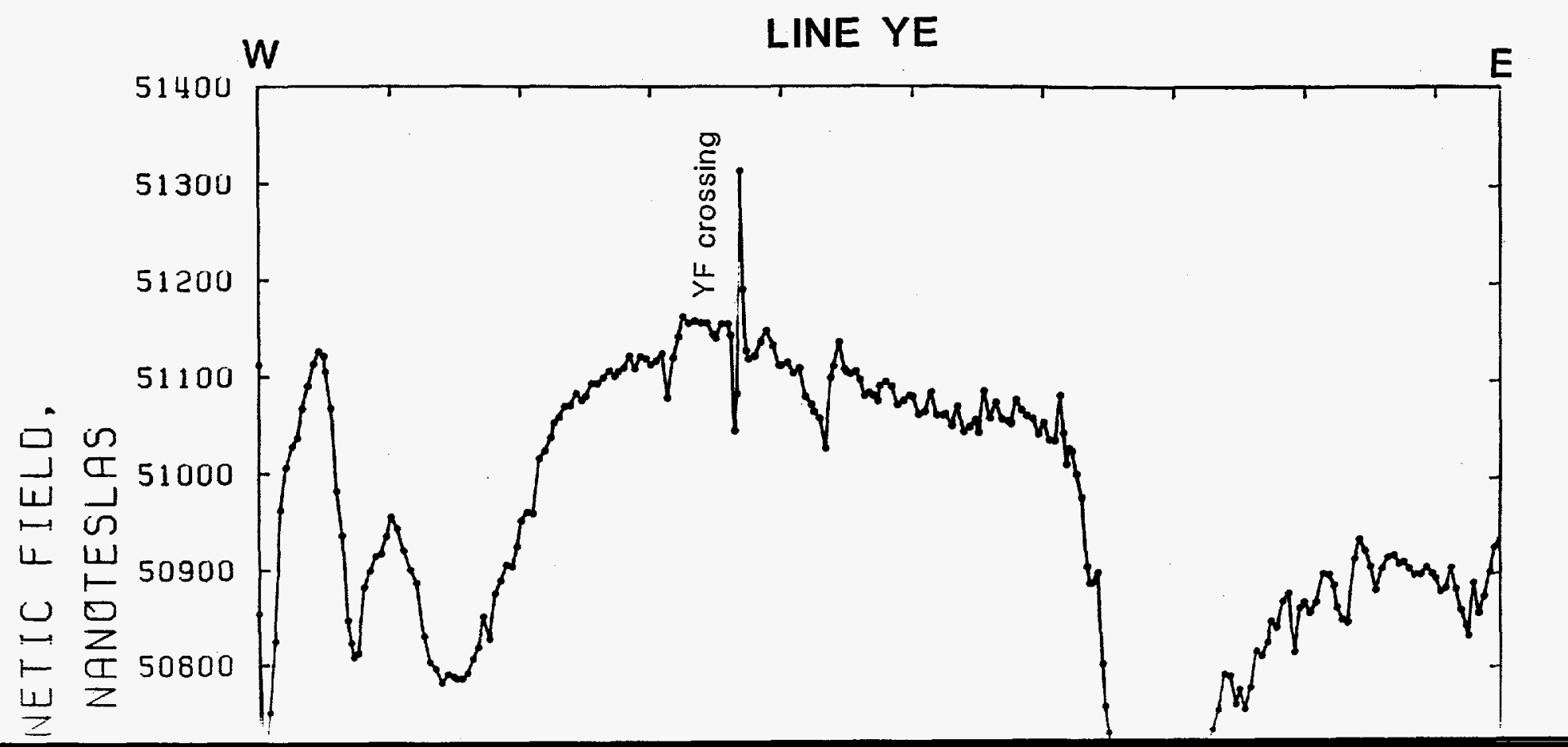



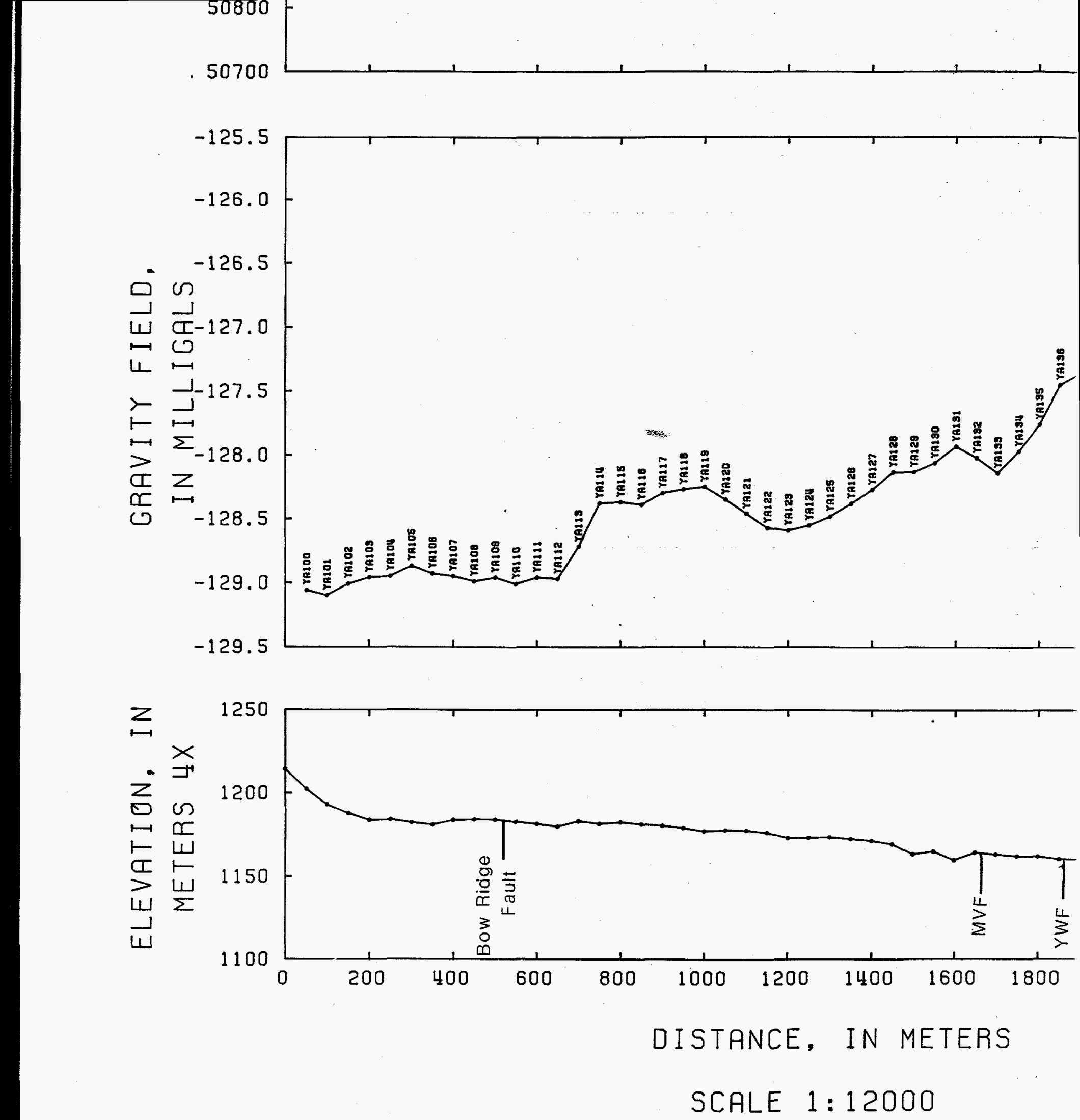

Figure 2a-Gravity, magnetic, and topography profile of line YA. Bouguer gra anomalies reduced for a density of $2.00 \mathrm{~g} / \mathrm{cm}^{3}$. Faults shown are from Scott anc (1984), Midway Valley fault (MVF) is from Lipman and McKay (1965). PCF, Paintbrush Canyon fault; YWF, Yucca Wash fault. 

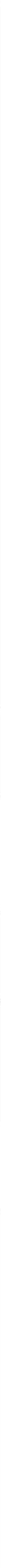

N METERS

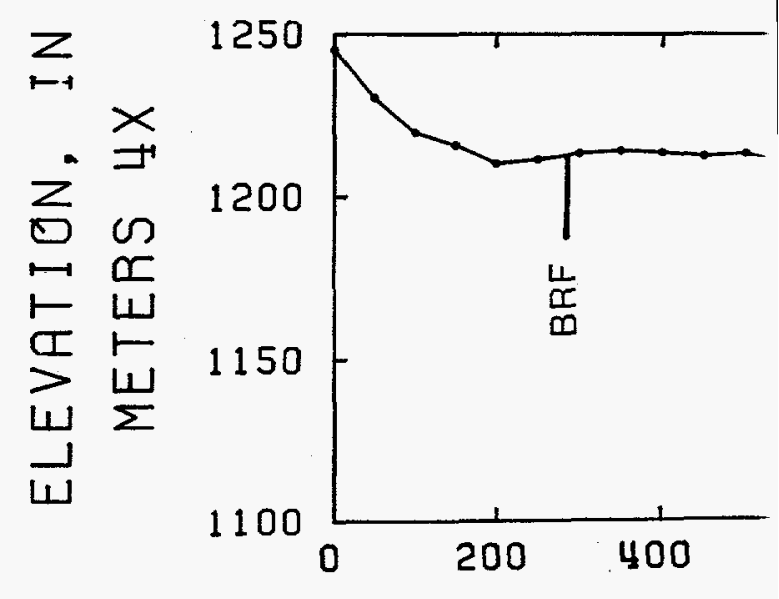

\section{0}

of line YA. Bouguer gravity shown are from Scott and Bonk nd McKay (1965). PCF,

DIST

SC

Figure $2 b-$ Gravity, magnetic, and top anomalies reduced for a density of 2.00 (1984). BRF, Bow Ridge fault; YWF, 


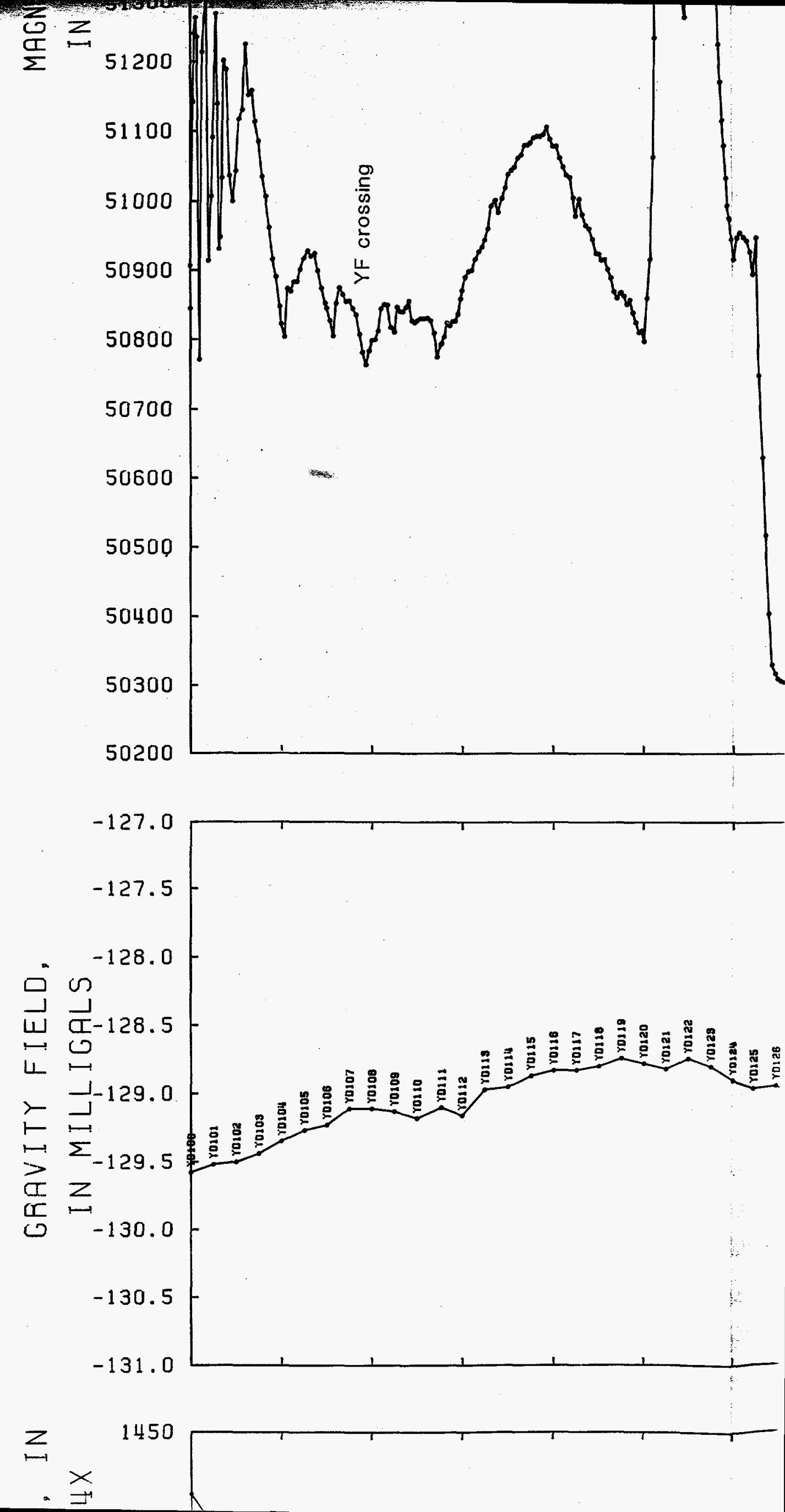



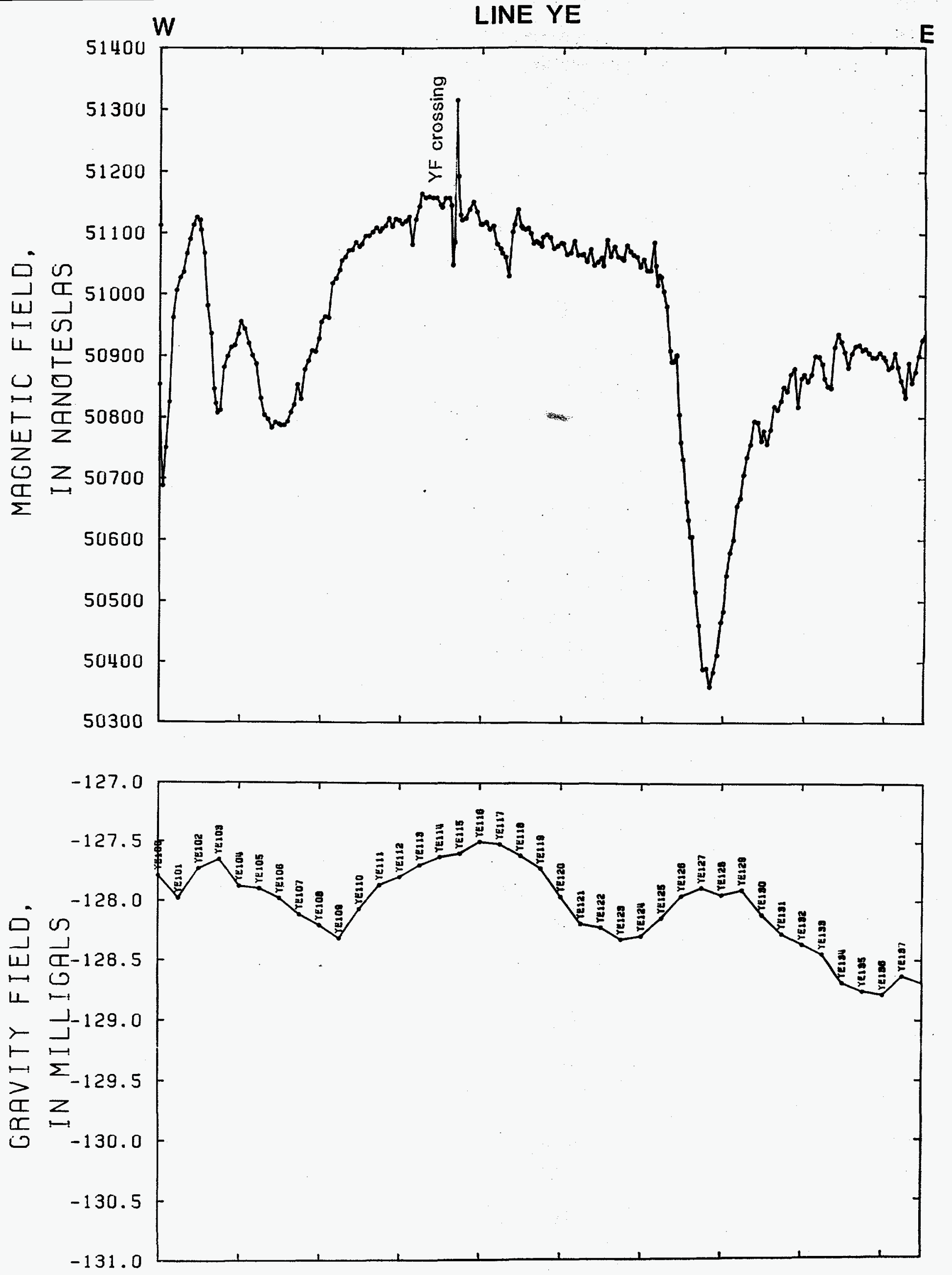

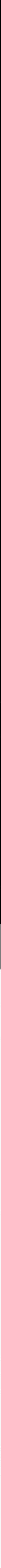

ravity, magnetic, and topography profile of line YC. Bouguer gravity uced for a density of $2.00 \mathrm{~g} / \mathrm{cm}^{3}$. Faults shown are from Scott and Bonk ramed fault; YWF, Yucca Wash fault.

Figure 2d-Gravity, magnetic, and topograph anomalies reduced for a density of $2.00 \mathrm{~g} / \mathrm{cm}^{2}$ (1984). F, unnamed fault; YWF, Yucca Wash 

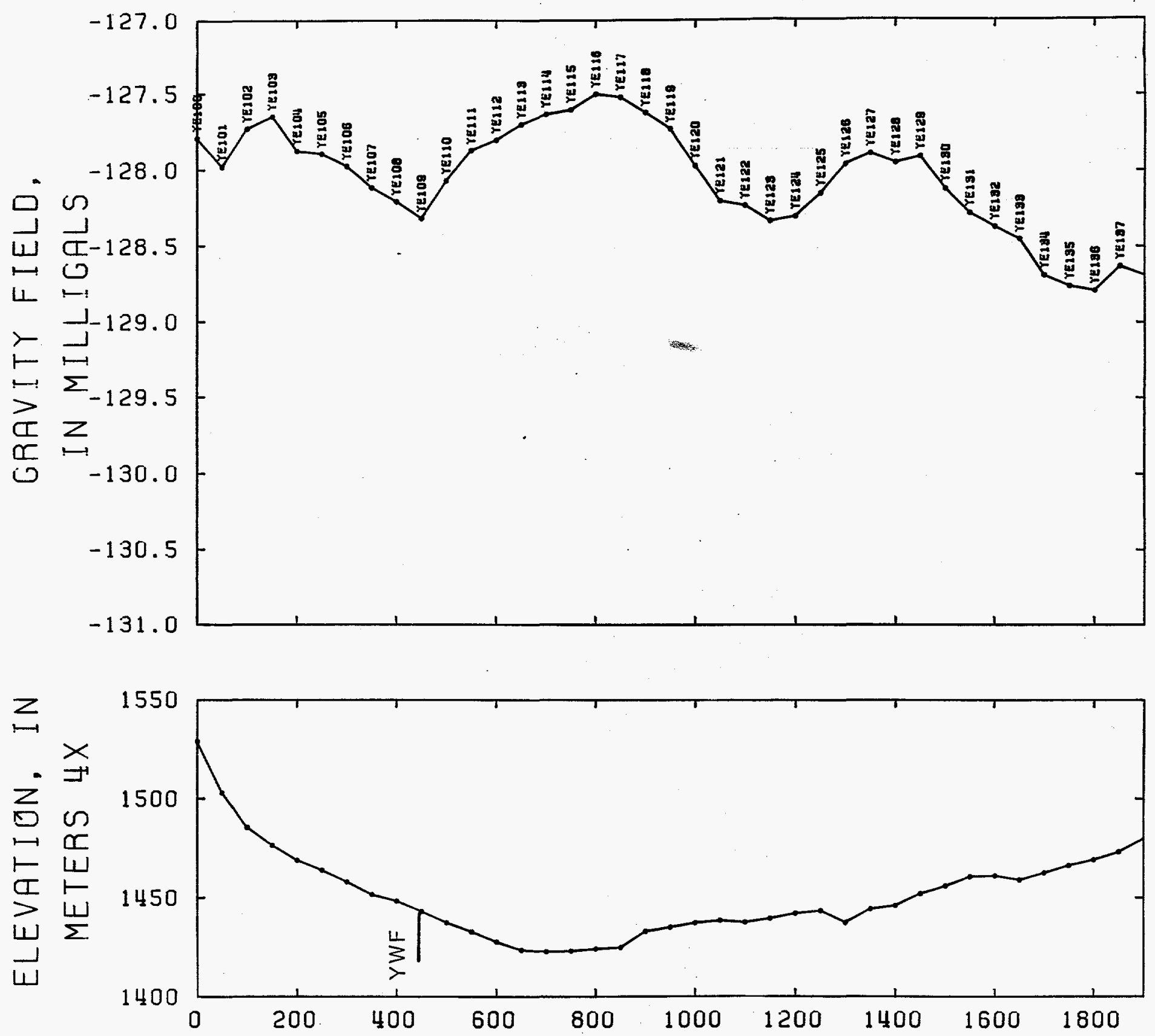

DISTANCE, IN METERS

\section{SCALE 1:12000}

Figure 2e-Gravity, magnetic, and topography profile of line YE. Bouguer gravity anomalies reduced for a density of $2.00 \mathrm{~g} / \mathrm{cm}^{3}$. Faults shown are from Scott and Bonk (1984). YWF, Yucca Wash fault.

This report is preliminary and has not been edited or reviewed for conformity with U.S. Geological Survey editorial standards or with the North American Stratigraphic Code. Any use of trade, firm, or product names is for descriptive purposes only and does not imply endorsement by the U.S. Government. 
U.S. DEPARTMENT OF THE INTERIOR

U.S. GEOLOGICAL SURVEY

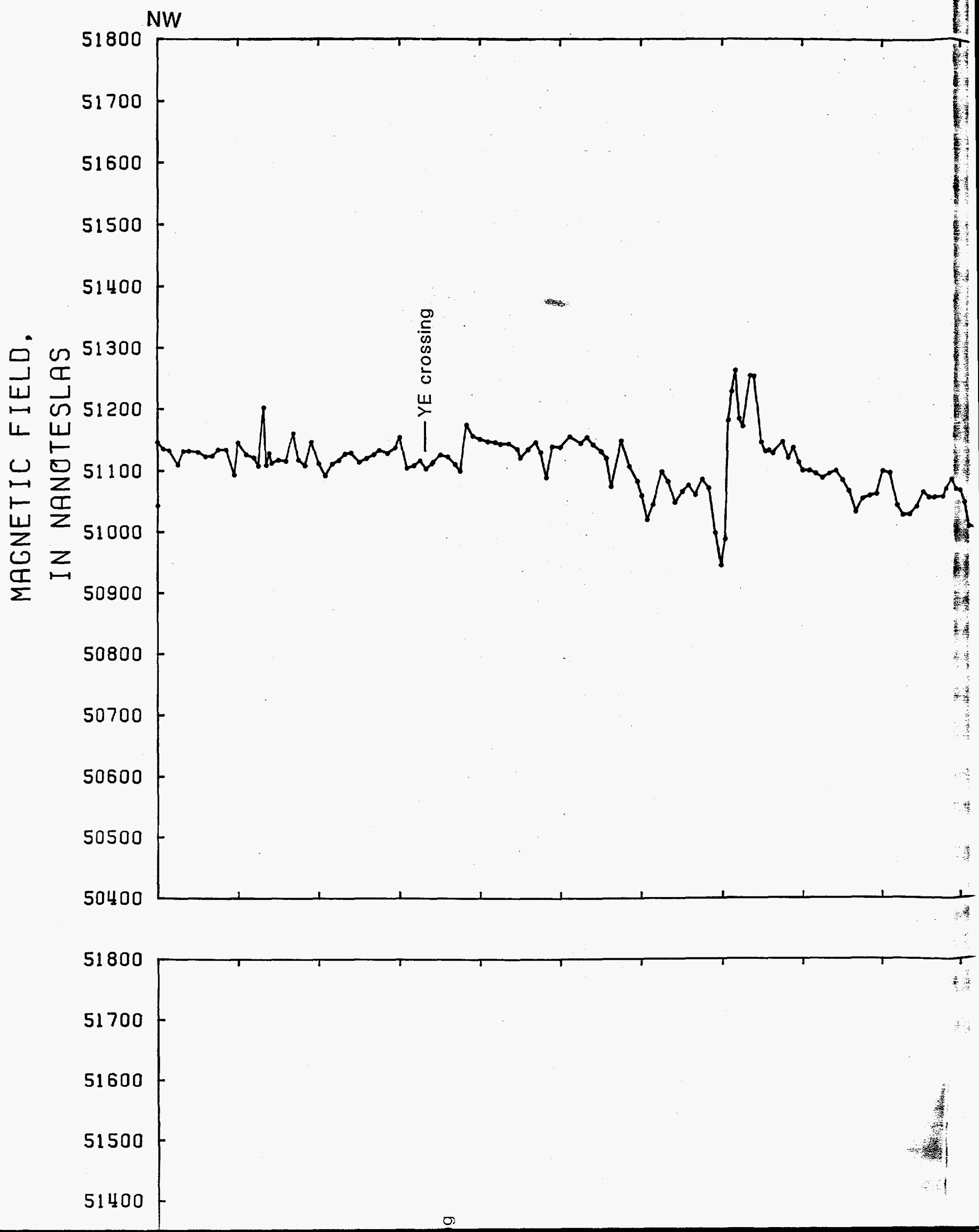



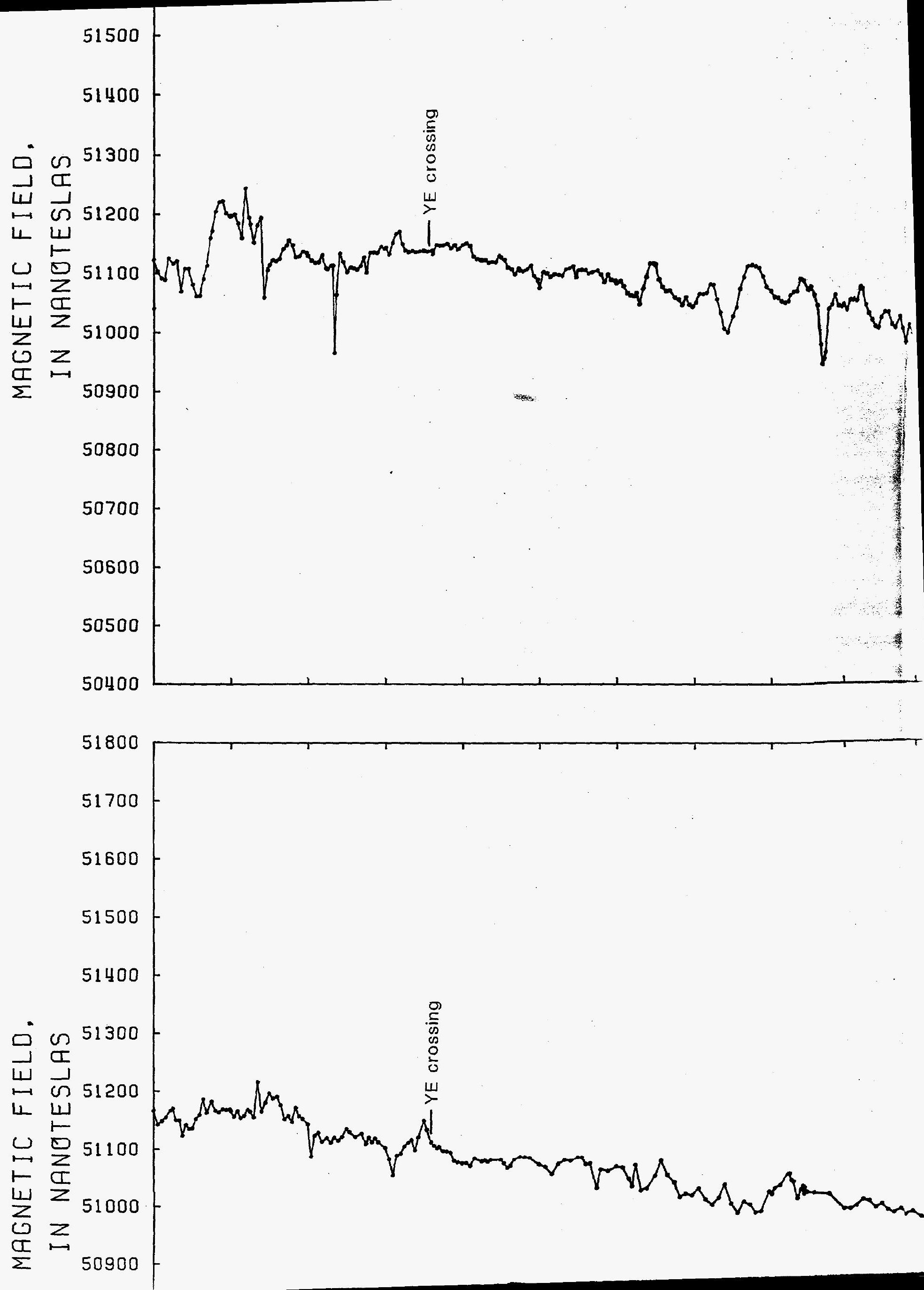

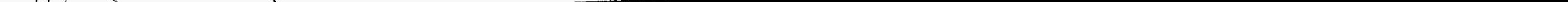


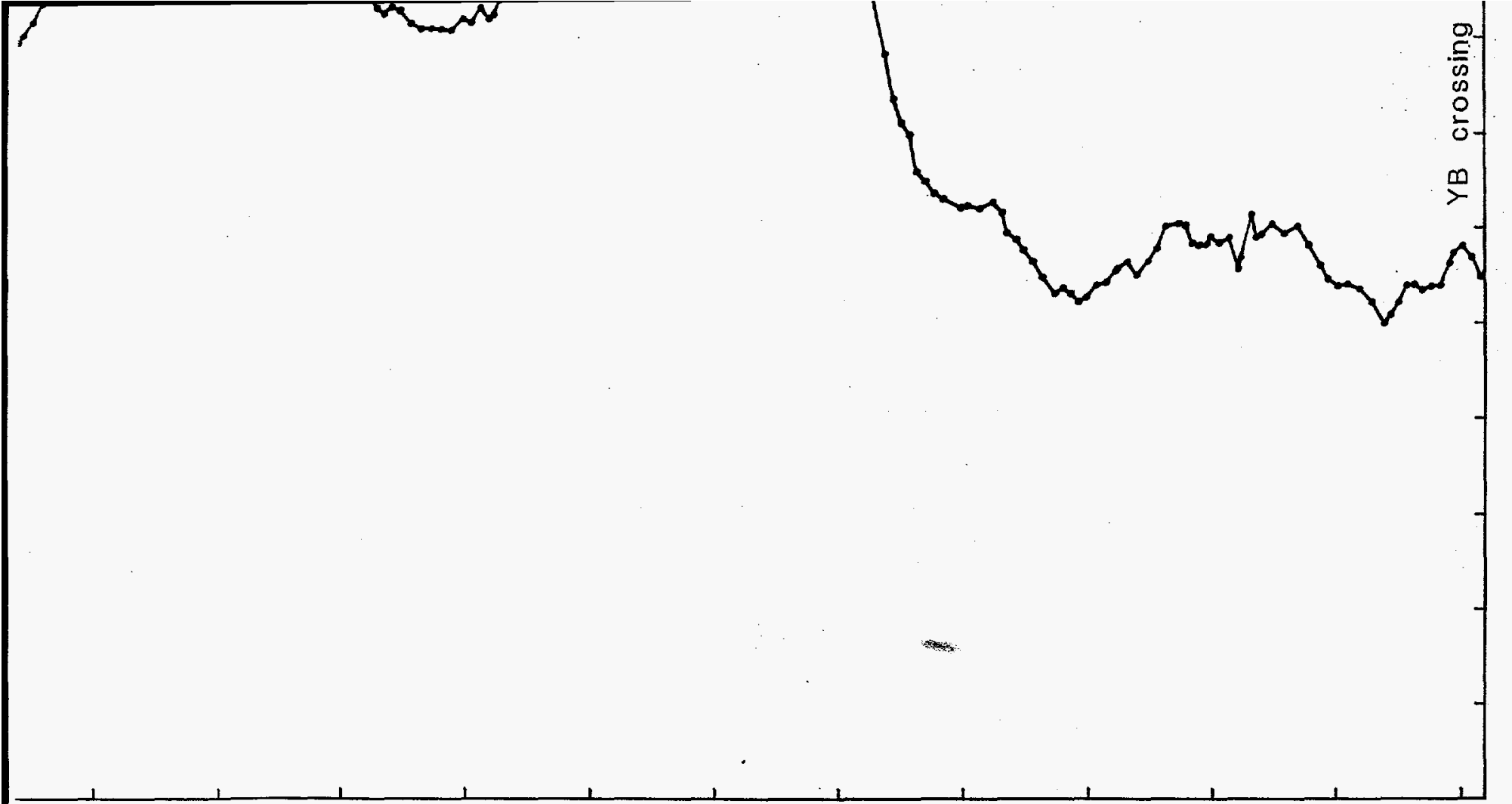



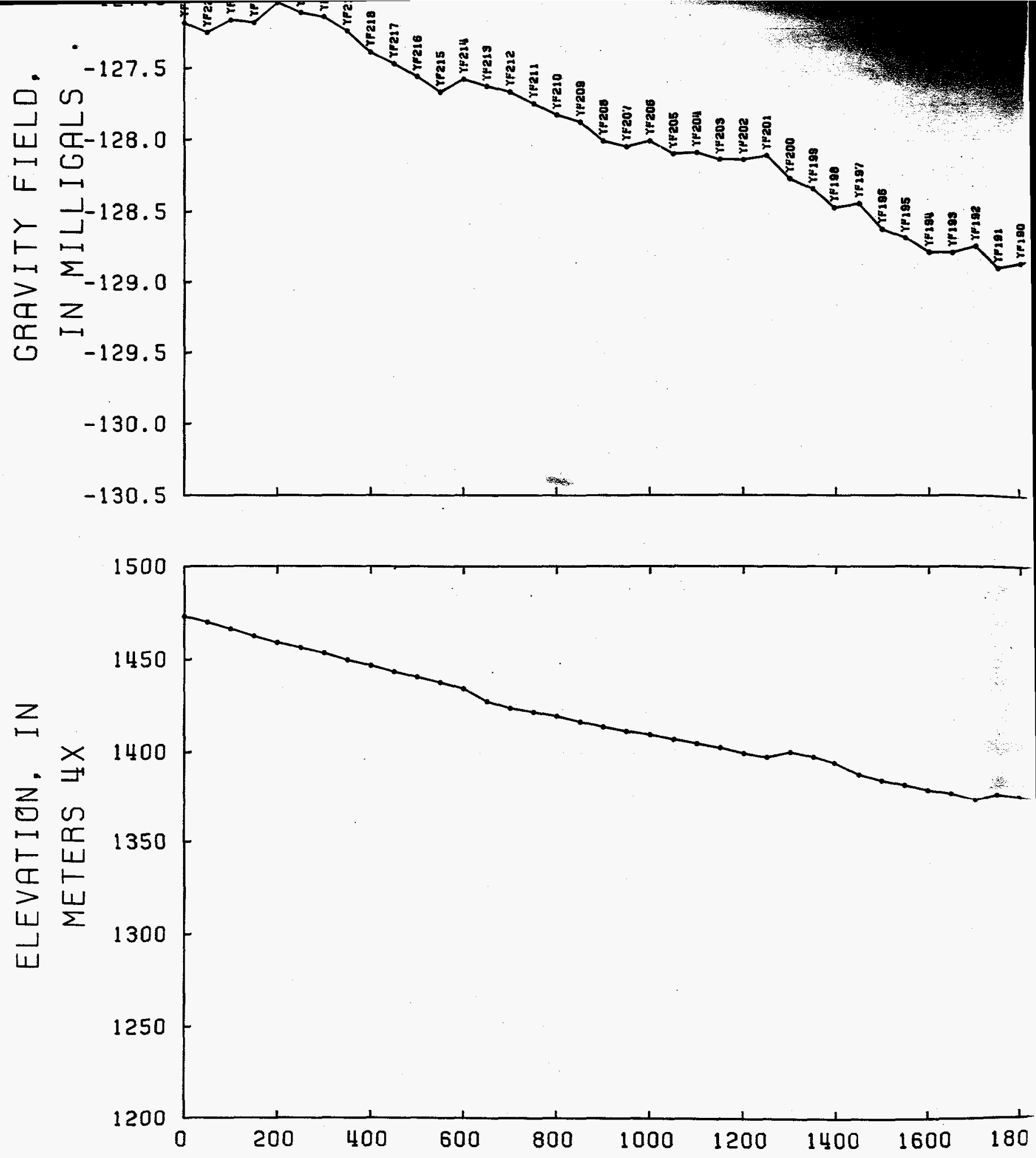
